\title{
The inflammatory activity of purified-ferulic acid from Tetragonia tetragonioides
}

\author{
Na-Hyeon Kim ${ }^{1} \cdot$ Hye-Jin Park ${ }^{1} \cdot$ Eun-Ho Lee ${ }^{1} \cdot$ Eun-Bi Cho $^{1} \cdot$ In-Kyu Kang $^{2}$ \\ - Young-Je Cho ${ }^{1}$
}

Received: 14 May 2019 / Accepted: 17 July 2019 / Published Online: 30 September 2019

(C) The Korean Society for Applied Biological Chemistry 2019

\begin{abstract}
In this study, an evaluation of the anti-inflammatory effect of ferulic acid isolated from Tetragonia tetragonioides in lipopolysaccharide (LPS) simulated RAW 264.7 cells was made. The chemical structure of the active compound was elucidated by ${ }^{1} \mathrm{H}-\mathrm{NMR},{ }^{13} \mathrm{C}-\mathrm{NMR}$, and FAB-MS, and was confirmed to be ferulic acid. Ferulic acid was purified via open column chromatography with Sephadex LH-20 and MCI gel CHP-20. To test the antiinflammatory effect of ferulic acid, LPS-stimulated RAW 264.7 cells were treated in subsequent experiments with different concentrations of ferulic acid $(5,10$, and $25 \mu \mathrm{g} / \mathrm{mL})$ and the levels of inflammatory cytokines and enzymes were also measured by the 3-[4,5-dimethylthiazol-2-yl]-2,5-diphenyltetrazolium bromide assay. Cell viability was above $95 \%$ at acid concentrations ranging from $5-25 \mu \mathrm{g} / \mathrm{mL}$. The results showed that $30 \%$ of the production of nitric oxide and $66 \%$ of prostaglandin $\mathrm{E}_{2}$ were inhibited by 25 $\mu \mathrm{g} / \mathrm{mL}$ of ferulic acid, it also inhibited the protein expression of both inducible nitric oxide synthase and cyclooxygenase- 2 by $70 \%$. Additionally, it inhibited the production of the pro-inflammatory cytokines, tumor necrosis factor- $\alpha$, interleukin- 6 , and interleukin$1 \beta$ by 40,75 , and $77 \%$, respectively. According to these results, the anti-inflammatory activity of ferulic acid was demonstrated via his implication in the inhibition of the expression and secretion of inflammatory substances in LPS-stimulated RAW 264.7 cells. Therefore, we concluded that ferulic acid can be used as a functional additive having anti-inflammatory activity.
\end{abstract}

Young-Je Cho $(\triangle)$

E-mail:yjcho@knu.ac.kr

${ }^{1}$ School of Food Science \& Biotechnology, Kyungpook National University, 80 Daehakro, Bukgu, Daegu 41566, Republic of Korea

${ }^{2}$ Department of Horticultural Science, Kyungpook National University, 80 Daehakro, Bukgu, Daegu 41566, Republic of Korea

This is an Open Access article distributed under the terms of the Creative Commons Attribution Non-Commercial License (http://creativecommons. org/licenses/by-nc/3.0/) which permits unrestricted non-commercial use, distribution, and reproduction in any medium, provided the original work is properly cited.
Keywords Anti-inflammation $\cdot$ Cytokine $\cdot$ Ferulic acid $\cdot$ RAW 264.7 cell $\cdot$ Tetragonia tetragonioide

\section{Introduction}

The inflammatory response is a set of reactions generated by a living organism in answer to an undergone aggression. This one can be of origin outside as a wound, a physical agent, a chemical agent, a bacterial infection, a trauma, or result from the inside of the living organism itself as in autoimmune pathologies. However, in spite the healing role of inflammation, severe or supported inflammation may cause chronic diseases such as degenerative arthropathy, allergic diseases, and hypertension [1,2]. When an inflammatory reaction occurs in the body, macrophages and mast cells at the site of injury secrete inflammatory mediators, which attract leukocytes and neutrophils to the damaged area. Neutrophils affect the permeability of vascular endothelial cells by secreting reactive oxygen species (ROS), proteinases, and elastases, which are activated to remove the invading pathogens [3]. Lipopolysaccharide (LPS), a major constituent in the external membrane of gramnegative bacteria, induces an immune response by enhancing the toll-like receptor 4 (TLR4) signaling in host macrophages [4]. LPS binds to LPS binding protein (LBP) and interacts with TLR4, which subsequently activates nuclear factor- $\kappa \mathrm{B}(\mathrm{NF}-\kappa \mathrm{B})$ through myeloid differentiation primary response gene 88 (MyD88), an adaptor protein, leading to the secretion of tumor necrosis factor$\alpha$ (TNF- $\alpha$ ), and interleukin-1 $\beta$ (IL-1 $\beta$ ) [5]. These inflammatory cytokines stimulate the expression of inducible nitric oxide synthase (iNOS) and cyclooxygenase-2 (COX-2), leading to excessive production of nitric oxide (NO) and prostaglandin $\mathrm{E}_{2}\left(\mathrm{PGE}_{2}\right)$, respectively [6]. Tetragonia tetragonioides, known as New Zealand spinach, is a perennial plant distributed in Korea, China, Japan, Australia, and South Africa. It grows well in dry and barren places such as rock gaps and gravel fields [7,8]. The white sticky juice 
that exudes from the broken stem/leaves of this plant has a protective effect on the stomach wall and has been used as an herbal remedies to cure and prevent stomach diseases such as gastritis and gastric ulcer [9,10]. Steryl glucoside, oxalic acid, cannabisin $\mathrm{B}$, cerebroside, $\beta$-carotene, and 4-hydroxybenzamide have been isolated from T. tetragonioides [11-14]. However, only few studies have focused on the separation and analysis of active ingredients from T. tetragonioides, and the beneficial effects of isolated single compounds have not been extensively investigated. In this study, we isolated a single compound, ferulic acid, from $T$. tetragonioides and evaluated its anti-inflammatory effect on LPSstimulated RAW 264.7 cells. Our results supplied with precious data which can allow the development of a natural anti-inflammatory substance.

\section{Material and Methods}

\section{Preparation of $T$. tetragonioides extract}

The procurement of T. tetragonioides was made at the level of the local market. To desiccate the biological material, it was put down inside the dry oven (Jeiotech, Daejeon, Korea) at $45{ }^{\circ} \mathrm{C} .1 \mathrm{~g}$ of $T$. tetragonioides powder, pulverized into 40 mesh, was put into 200 $\mathrm{mL}$ of distilled water and boiled until the volume decreases to 100 $\mathrm{mL}$. Then, the extract was stir-extracted by shaker incubator $(120$ $\mathrm{rpm}$ ) for $24 \mathrm{~h}$ at room temperature. The extract was filtered by using Whatman No. 1 filter paper (Whatman Inc, Piscataway, NJ, USA) and the filtrate was lyophilized and stored at $-70{ }^{\circ} \mathrm{C}$. If necessary, the extracts were concentrated in a rotary vacuum evaporator (Eyela NE, Tokyo, Japan) to the needful concentration.

\section{Determination of the extract phenolic content}

To calculate the phenolic content of each fraction of solvent, the Folin-Denis method was used. This method requires to take first $1 \mathrm{~mL}$ of the sample and a blank solution (distilled water), by adding to each of them $1 \mathrm{~mL}$ of $95 \%$ ethanol. Then, $5 \mathrm{~mL}$ of distilled water and $0.5 \mathrm{~mL}$ of $1 \mathrm{~N}$ Folin-Ciocalteu reagent (Junsei Chemical Co, Tokyo, Japan) were added as a color developing reagent. After, the mixture was left for $5 \mathrm{~min}$ for the color to develop, then $1 \mathrm{~mL}$ of $\mathrm{Na}_{2} \mathrm{CO}_{3}$ was added and the optical density (OD) was measured within $1 \mathrm{~h}$ at $725 \mathrm{~nm}$ (Optizen 3220UV, Mecasys, Daejeon, Korea). Concentrations were calculated from a standard curve constructed using gallic acid as a standard.

\section{Purification of solvent fractions and isolation of the active compound}

First, the extract was subjected to normal phase chromatography. Sephadex LH-20 (Pharmacia Co, Uppsala, Sweden), having the property to separate substances in function of their adsorbability, was added at the level of the column, and the mobile phase consisted of $60 \% \mathrm{EtOH}$. Components were eluted using $\mathrm{EtOH}$ $\rightarrow \mathrm{H}_{2} \mathrm{O}$ gradient system $(100 \rightarrow 0 \%)$ at a flow rate of $20 \mathrm{~mL} / \mathrm{min}$, and then concentrated and dried using TLC after identifying the phenolic compounds. Reverse phase chromatography was realized using MCI gel (Supelco, Bellefonte, PA, USA) as the stationary phase and gradient system of $\mathrm{H}_{2} \mathrm{O} \rightarrow \mathrm{MeOH}(0 \rightarrow 100 \%)$ as the eluting solvent. Then, the identified phenolic compounds were separated using TLC to isolate the active compound.

\section{Identification of the chemical structure of the active compound} Melting point determination: The melting point was determined by using a micro-electrothermal actuator (Fisher-Jhons, Mexico City, Mexico) with sample of $1 \mathrm{mg}$. Infrared spectroscopy: One milligram of the pure sample was mixed with $100 \mathrm{mg}$ of $\mathrm{KBr}$ powder (a halogenated alkali) under an appropriate pressure; then, IR spectroscopy was realised (Perkin-Elmer IR-1330, Perkin Elmer, Waltham, MA, USA). NMR: ${ }^{1} \mathrm{H}$ and ${ }^{13} \mathrm{C}-\mathrm{NMR}$ spectral data were acquired using AVANCE III HD $500 \mathrm{MHz}$ NMR spectrometer (Bruker, Germany) at KBSI Western Seoul center, using TMS [tetramethylsilane; $\left(\mathrm{CH}_{3}\right)_{4} \mathrm{Si}$ ] as a reference substance. $10 \mathrm{mg}$ of purified compound was solved at a ratio of 5 to $20 \%(\mathrm{~W} / \mathrm{V})$ to give deuterated methanol $\left(\mathrm{CD}_{3} \mathrm{OD}\right)$, which was used as the solvent for NMR. FAB-MS: One milligram of the solid sample was analysed by using negative ion FAB-MS (Jeol JMS-PX 300, Tokyo, Japan) in the decompressed phase of $10^{-4}-10^{-6} \mathrm{mmHg}$. Thioglycerol was used as the matrix, and electric current was emitted at 22-28 eV at determination conditions. The sample was bombarded with an ion source accelerated to $6-7 \mathrm{kV}$. The results of these tests showed that the active compound is ferulic acid.

\section{Hyaluronidase (HAase)-inhibitory assay}

HAase-inhibitory activity was determined according to the method of Reissig et al. [16]. The enzyme activity was determined by measuring the optimal density of glucoxazoline, induced and modified from $\mathrm{N}$-acetylglucosamine, which is released from sodium-hyaluronic acid (HA). The color is expressed by adding pdimethylaminobenzaldehyde (DMAB) (Sigma Chemical Co. Yongin, Korea). The assay was carried out as follows; $0.1 \mathrm{M}$ acetate buffer ( $\mathrm{pH} 3.5$ ) was mixed with $7,900 \mathrm{U} / \mathrm{mL}$ dissolved HAase (Wako Pure Chemical Industries, Osaka, Japan). First, $0.05 \mathrm{~mL}$ HAase and $0.1 \mathrm{~mL}$ sample solutions were mixed and cultured for $20 \mathrm{mins}$ at $37{ }^{\circ} \mathrm{C}$ then, $0.1 \mathrm{~mL}$ of $12.5 \mathrm{mM} \mathrm{CaCl}_{2}$ was added to mixture and reacted again for 20 mins. Next, $12 \mathrm{mg} / \mathrm{mL}$ of melted hyaluronic acid (substrate) was added and cultured for 40 min then $0.1 \mathrm{~mL}$ of $0.4 \mathrm{~N} \mathrm{NaOH}$ and $0.1 \mathrm{~mL}$ of $0.4 \mathrm{~N} \mathrm{~K}_{2} \mathrm{~B}_{4} \mathrm{O}_{7}$ were added to mixture. The mixture was boiled in a water bath for $3 \mathrm{~min}$ and completely cooled. After adding $3 \mathrm{~mL}$ of DMAB, as a color forming reagent, to the cooled reaction product were incubated at $37^{\circ} \mathrm{C}$ for $20 \mathrm{~min}$. Finally, the inhibitory activity was calculated by using the data of absorbance taken at $585 \mathrm{~nm}$. The following equation was used to make the calculation: Inhibition ratio $(\%)=$ (1-absorbance of sample group/absorbance of control group $) \times$ 100 . 


\section{Cell culture}

The culture of cells was made on purchased Mouse macrophage RAW 264.7 cells from the Korean Cell Line Bank (Seoul, Republic of Korea). The cells were cultured in Dulbecco's Modified Eagle's Medium (DMEM, HyClone, GE Healthcare Life Sciences, Chicago, IL, UT, USA) supplemented with $10 \%$ fetal bovine serum (FBS, HyClone) and $100 \mathrm{U} / \mathrm{mL}$ penicillin-streptomycin (HyClone) at $37{ }^{\circ} \mathrm{C}$ in a $5 \% \mathrm{CO}_{2}$ incubator.

\section{MTT assay}

The method used by Carmichael et al. [17] was applied to determinate the cytotoxic effect of ferulic acid by using the 3-[4,5dimethylthiazol-2-yl]-2,5-diphenyltetrazolium bromide (MTT) assay. RAW 264.7 cells were cultured at a concentration of $5 \times 10^{3}$ cells $/ \mathrm{mL}$ in 48 -well plates. Samples $(50 \mu \mathrm{L})$ of different concentrations of ferulic acid $(5,10,25,50$, and $100 \mu \mathrm{g} / \mathrm{mL})$ were added to the cells and incubated for $24 \mathrm{~h}$ at $37^{\circ} \mathrm{C}$ and $5 \% \mathrm{CO}_{2}$. Control group cells were not treated with ferulic acid. After added MTT solution (Sigma Chemical Co.) at $5 \mathrm{mg} / \mathrm{mL}$ and incubated for $4 \mathrm{~h}$, then the medium was removed, dimethylsulfoxide was added to each well and left at room temperature for $30 \mathrm{~min}$. Finally, the absorbance values were detected at $540 \mathrm{~nm}$ using an enzyme-linked immunosorbent assay (ELISA) reader (Spectrostar Nano, BMG Labtech, Ortenberg, Germany).

\section{Measurement of NO production}

The NO concentration in cell supernatants was identified as nitrite and nitrate. The Griess reagent (Sigma Chemical Co.) was used to take measures because the oxidation of nitrite to nitrate is stabilized. Briefly, $5 \times 10^{4}$ cells $/ \mathrm{mL}$ of RAW 264.7 macrophages were sowed in 96-well plates and cultivated for $24 \mathrm{~h}$ at $37^{\circ} \mathrm{C}$ in $5 \% \mathrm{CO}_{2}$. Next, the cells, apart from the normal group, were stimulated with $1 \mu \mathrm{g} / \mathrm{mL}$ LPS then treated with different concentrations of ferulic acid $(5,10$, and $25 \mu \mathrm{g} / \mathrm{mL})$ for $24 \mathrm{~h}$ at $37^{\circ} \mathrm{C}$. In the control group, the ferulic acid was replaced by an equal amount of distilled water. After, $100 \mu \mathrm{L}$ of the cell culture supernatants was incubated for $24 \mathrm{~h}$ in a 96 well plate and reacted with $100 \mu \mathrm{L}$ of Griess reagent in the dark room for 10 mins. The NO production was determined by measuring the absorbance at $540 \mathrm{~nm}$.

\section{Western blotting analysis}

RAW 264.7 cells were seeded at a density of $5 \times 10$ cells/well in a 6 well plate for $24 \mathrm{~h}$. Then, the cells were pre-treated with $1 \mu \mathrm{g} /$ $\mathrm{mL}$ of LPS and added to various concentrations $(5,10$, and $25 \mu \mathrm{g} /$ $\mathrm{mL}$ ) of the ferulic acid, followed by incubation for $18 \mathrm{~h}$. Cells were washed with cold PBS, lysed with $100 \mu \mathrm{L}$ of radio-immunoprecipitation assay (RIPA) buffer $(\mathrm{pH} 7.4)$ and harvested by centrifugation (1730R, Gyrozen, Seoul, Korea) at 12,000 rpm and $4{ }^{\circ} \mathrm{C}$ for $20 \mathrm{~min}$. Then, the supernatant was put into a new tube and the Bradford assay was realized to determinate the concentration of The transferred membrane was incubated with 5\% skimmed milk blocking buffer (in Tris-Buffered Saline Tween-20 (TBST)) for $1 \mathrm{~h}$ at room temperature. A total of $20 \mu \mathrm{L}$ of protein was separated by $10 \%$ sodium dodecyl sulfate-polyacrylamide gel electrophoresis and transferred to semi-dry transfer cell machine (Bio-Rad Laboratories, Inc., Hercules, CA, USA) using polyvinylidene difluoride membrane (Millipore Corp, Billerica, MA, USA). The blocked membrane was washed 3 times every 10 min with TBST and then reacted with the diluted primary antibodies, iNOS (1:1,000, BD Bioscience, Sanjose, CA), COX2 (1:1,000, Cayman, Ann arbor, MI), and glyceraldehyde 3phosphate dehydrogenase $(1: 1,000$, Santa Cruz Biotechnology, Inc., Santa Cruz, CA), at $4{ }^{\circ} \mathrm{C}$ for overnight. Again, the membrane was washed 3 times every 10 min with TBST, and incubated with the diluted secondary antibodies, Mouse anti-rabbit IgG horseradish peroxidase (HRP) $(1: 1,000$, Santa Cruz) and bovine anti-goat IgG HRP (1:1,000, Santa Cruz), for $2 \mathrm{~h}$ at room temperature. After be washed 3 times, the membranes were reacted with enhanced chemiluminescence (ECL) solution (Millipore Corp.) and the band was analyzed in a dark room by using Molecular Imager (Bio-Rad Laboratories, Inc.).

\section{$\mathrm{PGE}_{2}$ and cytokine assay}

$5 \times 10^{5}$ cells $/ \mathrm{mL}$ of RAW 264.7 macrophages were seeded in 96well plates and were stimulated with $1 \mu \mathrm{g} / \mathrm{mL}$ LPS. Next cell were treated with different concentrations of ferulic acid $(5,10$, and $25 \mu \mathrm{g} / \mathrm{mL}$ ) for $24 \mathrm{~h}$ at $37^{\circ} \mathrm{C}$ then cell culture media were collected. Enzyme immunoassay kits (R\&D systems Inc., Minneapolis, MN, USA) were used for the determination of $\mathrm{PGE}_{2}, \mathrm{TNF}-\alpha$, and IL-1 $\beta$. The content of each cytokine, such as TNF- $\alpha$, and IL- $1 \beta$, was calculated by using the standard curve ensuing from the reaction of the standard material.

\section{Statistical analysis}

All data was presented as means \pm SD from 3 independent experiments. The data were analyzed by SPSS 7.5 for window program (Statistical Package for Social Science, Chicago, USA) and used one-way ANOVA, followed by Duncan's multiple range tests. A $p$-value $<0.05$ was considered to indicate a statistically significant difference.

\section{Results and Discussion}

\section{Purification and identification of the anti-inflammatory} compound in $T$. tetragonioides

$30 \mathrm{~g}$ of freeze-dried T. tetragonioide were extracted by the ethanol and then mixed with $200 \mathrm{~mL}$ of water/ethyl acetate/n-butanol, accommodating 3 solvent fractions. The Solvents from the three fractions were removed, diluted with distilled water to certain concentrations, and then their inhibitory activities against HAase were examined. The layer of water showed the strongest inhibitory activity. Consequently, it was eluted by Sephadex LH-20 and MCI gel CHP-20 column chromatography to separate the compound 
Table 1 Spectroscopic data of compound isolated from T. tetragonioides

\begin{tabular}{cl}
\hline \hline Melting point $\left({ }^{\circ} \mathrm{C}\right)$ & \multicolumn{1}{c}{174} \\
\hline FAB-MS $(\mathrm{m} / \mathrm{z})$ & \\
\hline${ }^{1} \mathrm{H}-\mathrm{NMR}$ & $\delta: 3.88\left(3 \mathrm{H}, \mathrm{s}, \mathrm{H}-\mathrm{OCH}{ }_{3}\right), 7.59(1 \mathrm{H}, \mathrm{d}, J=15.8 \mathrm{~Hz}, \mathrm{H}-7), 6.31(1 \mathrm{H}, \mathrm{d}, J=15.8 \mathrm{~Hz}, \mathrm{H}-8), 7.15(1 \mathrm{H}, \mathrm{d}, J=1.7 \mathrm{~Hz}, \mathrm{H}-2)$, \\
& $7.04(1 \mathrm{H}, \mathrm{dd}, J=1.7$ and $8.1 \mathrm{~Hz}, \mathrm{H}-6), 6.81(1 \mathrm{H}, \mathrm{d}, \mathrm{J}=8.1 \mathrm{~Hz}, \mathrm{H}-5)$ \\
\hline${ }^{13} \mathrm{C}-\mathrm{NMR}$ & $\delta: 49.3(\mathrm{C}-\mathrm{OCH}), 171.1(\mathrm{C}-9), 147.1(\mathrm{C}-7), 116.0(\mathrm{C}-8), 116.6(\mathrm{C}-5), 111.8(\mathrm{C}-2), 149.4(\mathrm{C}-3), 124.1(\mathrm{C}-6), 127.9$ \\
& $(\mathrm{C}-1), 150.5(\mathrm{C}-4)$ \\
\hline
\end{tabular}

responsible for the HAase inhibitory activity.

The melting point of the cleansed isolated compound turned out to be $174{ }^{\circ} \mathrm{C}$ and its molecular weight was $194.19 \mathrm{~m} / \mathrm{z}$ according to FAB-MS. A summit of methoxy typical was shown by this compound at $3.88 \mathrm{ppm}$ in spectre ${ }^{1} \mathrm{H}-\mathrm{NMR}$, what refers to a structure in which it has a bound of a methoxy group instead of an $\mathrm{OH}$ group in the position of $\mathrm{C}-3$ of caffeic acid. The doublet signals at $7.59 \mathrm{ppm}$ and $6.31 \mathrm{ppm}, J=15.8 \mathrm{~Hz}$, represented the peaks of $\mathrm{H}-7$ and $\mathrm{H}-8$, respectively. It can be concluded that they are coupled one to another in the trans form [18]. The doublet signal at $7.15 \mathrm{ppm}, J=1.7 \mathrm{~Hz}$, represented the peak of $\mathrm{H}-2$; it was meta-coupled with H-6. The double doublet signal at $7.04 \mathrm{ppm}$, $J=1.7$ and $8.1 \mathrm{~Hz}$, represented the peak of H-6. These results were coherent to those obtained by Kim and others [19]. Signal of the group methoxy and the group ketone C-9 were observed at 49.3 ppm and at $171.1 \mathrm{ppm}$ respectively in C-NMR spectrum. C-7 and C-8 signals were observed at 147.1 at $116.0 \mathrm{ppm}$ respectively, what refers to a double bound of a typical cinnamic acid compound. The C-5 signal was shifted up field to $116.6 \mathrm{ppm}$ due to the attachment of the $\mathrm{OH}$ group to the adjacent carbon. A signal at 111.8 ppm represents the peak of $\mathrm{C}-2$, it was shown similar to $\mathrm{C}$ 5 when the $\mathrm{OH}$ group is present at $\mathrm{C}-3$, but because the methoxy group is substituted, it is shifted up field. Gentry et al. [20] showed that the C-5 and C-2 spectra of hycandinic acid ester were shifted up field by about 5 ppm, and the C-3 and C-4 signals were spaced by about $1 \mathrm{ppm}$. This indicates that the $\mathrm{OH}$ group at $\mathrm{C}-3$ is substituted with a methoxy group. The signal of C-6 showed a characteristic peak at $124.1 \mathrm{ppm}$, while the signal of C-1 showed a characteristic peak at 127.9 ppm. Signals of C-4 and C-3 were influenced by the $\mathrm{OH}$ and methoxy groups, and were shifted downfield to 150.5 and $149.4 \mathrm{ppm}$, respectively. According to this information, this compound was identified as ferulic acid.

\section{HAase-inhibitory activity of ferulic acid}

Upon inflammation, activated HAase hydrolyzes high-molecularweight HA, which fills the intercellular spaces, into low-molecularweight HA. Due to extravasation of neutrophils and lymphocytes from blood vessels, HAase contributes to inflammatory and allergic reactions [21]. Accordingly, inhibition of HAase is necessary to suppress inflammation by maintaining the polymeric form of HA. As shown in Fig. 1, ferulic acid isolated from T. tetragonioides extract was found to inhibit HAase activity by $97.6 \%$ at a concentration of $200 \mu \mathrm{g} / \mathrm{mL}$, and showed a stronger inhibitory activity than that of pyrrolidine dithiocarbonate (PDTC), a known

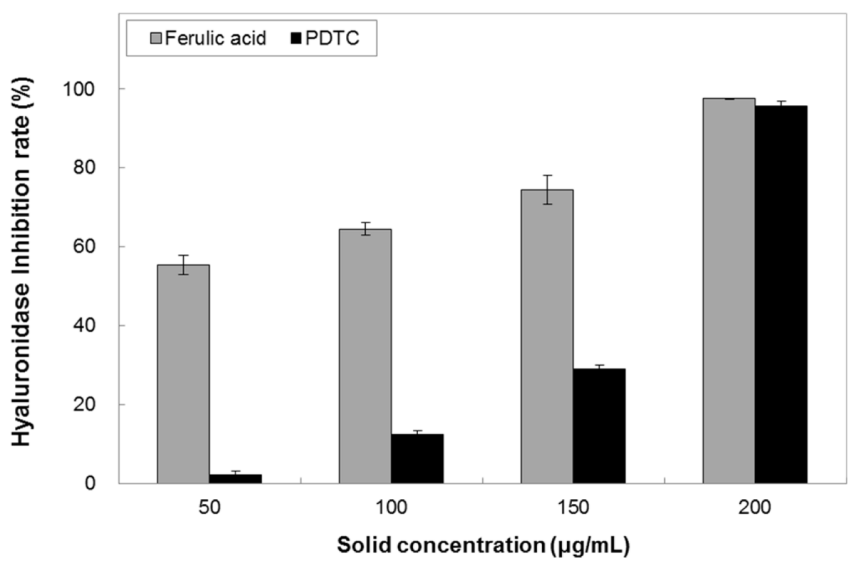

Fig. 1 Inhibitory activity of ferulic acid isolated from $T$. tetragonioides extract on HAase enzyme. The presented results are means \pm SD of three independent experiments. Means with different letters (a-e) above the bars for the same material are significantly different at the threshold of $5 \%$ of probability $(p<0.05)$ according to the test of multiple range of Duncan

NF- $\kappa \mathrm{B}$ inhibitor. In the study carried out by Park [22], 1,000 $\mu \mathrm{M}$ of each vanillic acid, caffeic acid, and quercetin, obtained from Rubus coreanus fruit, exhibited HAase-inhibitory activities of 27.4, 29.3, and 50.8\%, respectively. These results showed that ferulic acid isolated from T. tetragonioides has a superior HAaseinhibitory effect. Therefore, additional experiments were conducted to confirm its anti-inflammatory effect in LPS-stimulated RAW 264.7 cells.

\section{Effect of ferulic acid on cell viability}

The viability of RAW 264.7 cells treated with ferulic acid was measured via an MTT assay (Fig. 2). Cell viability decreased significantly, as ferulic acid concentrations increased (5, 10, 25, 50 , and $100 \mu \mathrm{g} / \mathrm{mL}$ ). For example, from 50 to $100 \mu \mathrm{g} / \mathrm{mL}$ of concentrations, cell viability passed from 80 to $59 \%$. This demonstrates that ferulic acid has an inhibitory effect on cell viability at high concentrations. Since ferulic acid concentrations ranging from $5-25 \mu \mathrm{g} / \mathrm{mL}$ were associated with cell viability values above $95 \%$, concentrations of 5,10 , and $25 \mu \mathrm{g} / \mathrm{mL}$ were used in all ulterior experiments.

Inhibitory effect of ferulic acid on $\mathrm{NO}$ and $\mathrm{PGE}_{\mathbf{2}}$ production Nitric oxide synthase (NOS) catalyzes the production of NO from L-arginine. In the body, NO can easily pass through cell membranes 


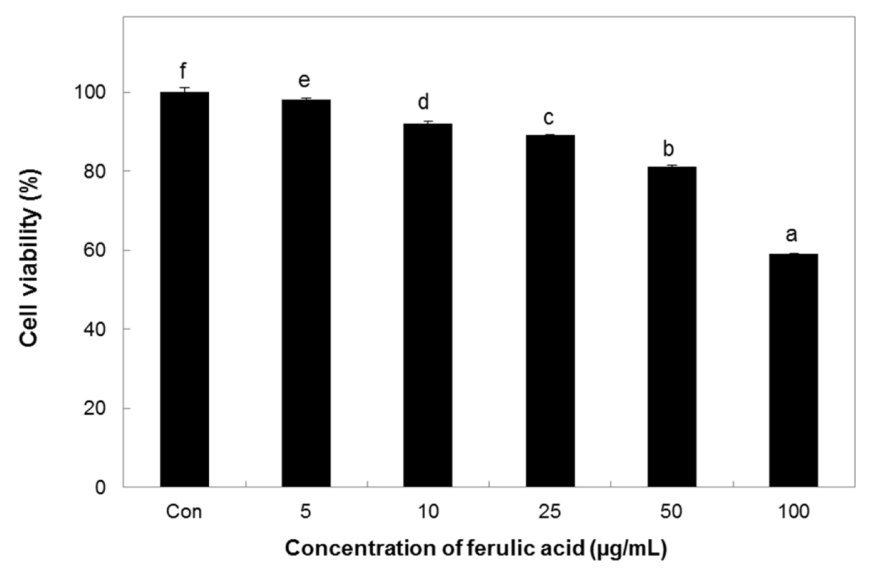

Fig. 2 The cell viability of RAW 264.7 cells treated with increasing concentrations of ferulic acid. During a period of $24 \mathrm{~h}$ a treatment of cells was made with different concentrations of ferulic acid $(5,10,25,50$ and $100 \mu \mathrm{g} / \mathrm{mL}$ ). Cell viability was measured using MTT assay. The presented results are means \pm SD of three independent experiments. Means with different letters (a-e) above the bars for the same material are significantly different at the threshold of $5 \%$ of probability $(p<0.05)$ according to the test of multiple range of Duncan

and transmit signals between cells in the immune system and the nervous system [23]. To confirm the inhibitory effect of ferulic acid on NO production, LPS-induced RAW 264.7 cells were treated with different concentrations of ferulic acid $(5,10$, and 25 $\mu \mathrm{g} / \mathrm{mL})$. As shown in Fig. 3A, NO production in the LPS $(1 \mu \mathrm{g} /$ $\mathrm{mL}$ )-stimulated cells increased nearly 3 times comparing to that in the unstimulated cells. However, NO production was found to decrease significantly in the cells treated with ferulic acid in a concentration-proportional manner, as compared with that in the

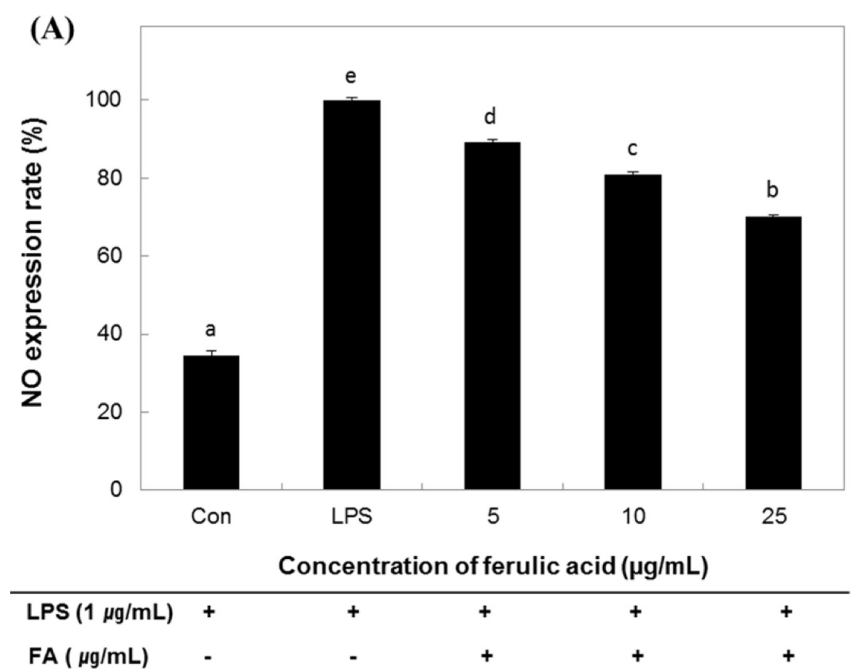

\section{LPS-stimulated cells.}

$\mathrm{PGE}_{2}$, an inflammatory mediator that induces pain and fever, is biosynthesized from arachidonic acid by the action of COX enzyme [24]. To confirm the inhibitory effect of ferulic acid on $\mathrm{PGE}_{2}$ production, LPS-stimulated RAW 264.7 cells were treated with different concentrations $(5,10,25 \mu \mathrm{g} / \mathrm{mL})$ of ferulic acid and $\mathrm{PGE}_{2}$ levels were measured (Fig. $3 \mathrm{~B}$ ). $\mathrm{PGE}_{2}$ production in the cells stimulated with $1 \mu \mathrm{g} / \mathrm{mL}$ LPS was found to be nearly 10 times higher than that in the unstimulated cells. However, it decreased significantly in the cells treated with ferulic acid in a concentration-dependent manner, as compared with the values in the LPS-stimulated cells.

\section{Inhibitory effect of ferulic acid on iNOS and COX-2 protein expression}

Unlike endothelial NOS (eNOS), which is constantly expressed to maintain the homeostasis of the human body, iNOS is expressed only in macrophages activated by different stimuli such as LPS; iNOS promotes excessive NO production and induces inflammation [25]. To corroborate the inhibitory effect of ferulic acid on iNOS protein expression, LPS-stimulated RAW 264.7 cells were treated with different concentrations of ferulic acid $(5,10$, and $25 \mu \mathrm{g} / \mathrm{mL})$ (Fig. 4A). The expression level of iNOS in the cells stimulated with $1 \mu \mathrm{g} / \mathrm{mL}$ LPS was nearly 5 times higher than that in the unstimulated cells. In addition, iNOS expression levels were revealed to decrease significantly in cells treated with ferulic acid in a concentration-dependent manner, as compared with that in the LPS-stimulated cells. In particular, $25 \mu \mathrm{g} / \mathrm{mL}$ ferulic acid exhibited $70 \%$ inhibition rate depending on the band density ratio of $\beta$-actin. Since ferulic acid was revealed to inhibit both NO production and iNOS protein expression, it was concluded that ferulic acid inhibits

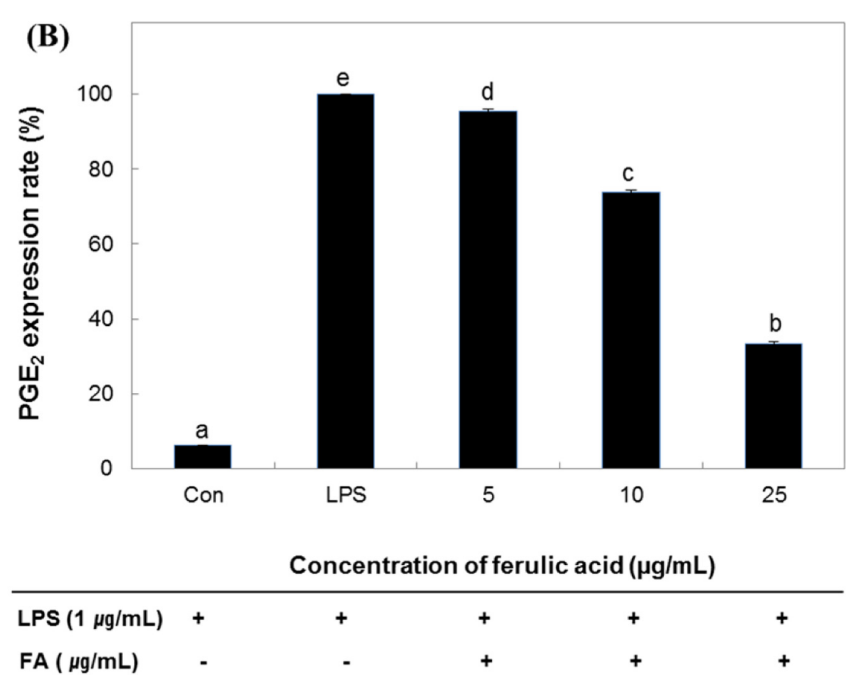

Fig. $3 \mathrm{NO}(\mathrm{A})$ and $\mathrm{PGE}_{2}$ (B) production in RAW 264.7 cells treated with different concentrations ferulic acid. During a period of 24 h a treatment of cells was made with different concentrations of ferulic acid $(5,10$, and $25 \mu \mathrm{g} / \mathrm{mL})$ and LPS $(1 \mu \mathrm{g} / \mathrm{mL})$. The totals of nitrate and PGE in the supernatant were evaluated by Griess reagent and ELISA, respectively. The presented results are means \pm SD of three independent experiments. Means with different letters (a-e) above the bars for the same material are significantly different at the threshold of $5 \%$ of probability $(p<0.05)$ according to the test of multiple range of Duncan 
(A)

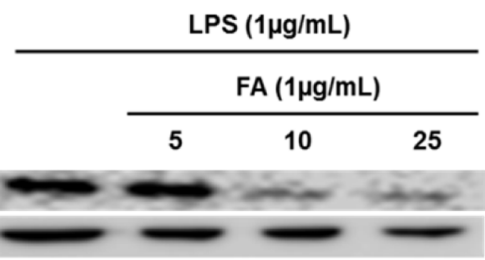

iNOS
$\beta$-actin

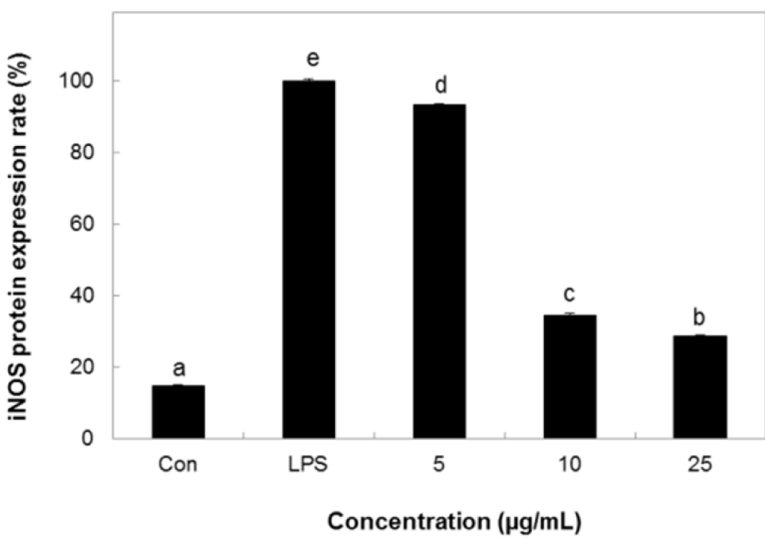

(B)
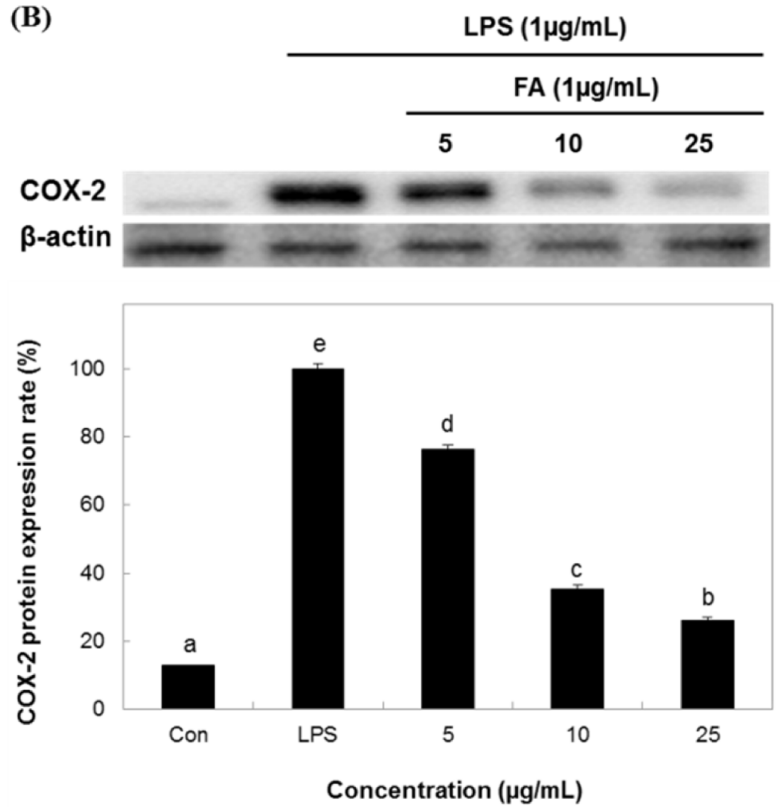

Fig. 4 Expression levels of iNOS (A) and COX-2 (B) in RAW 264.7 cells treated with different concentrations of ferulic acid. During a period of $24 \mathrm{~h}$ a treatment of cells was made with different concentrations of ferulic acid $(5,10$, and $25 \mu \mathrm{g} / \mathrm{mL})$ and LPS $(1 \mu \mathrm{g} / \mathrm{mL})$. Control cells were incubated with vehicle alone. The presented results are means $\pm \mathrm{SD}$ of three independent experiments. Means with different letters (a-e) above the bars for the same material are significantly different at the threshold of $5 \%$ of probability $(p<0.05)$ according to the test of multiple range of Duncan

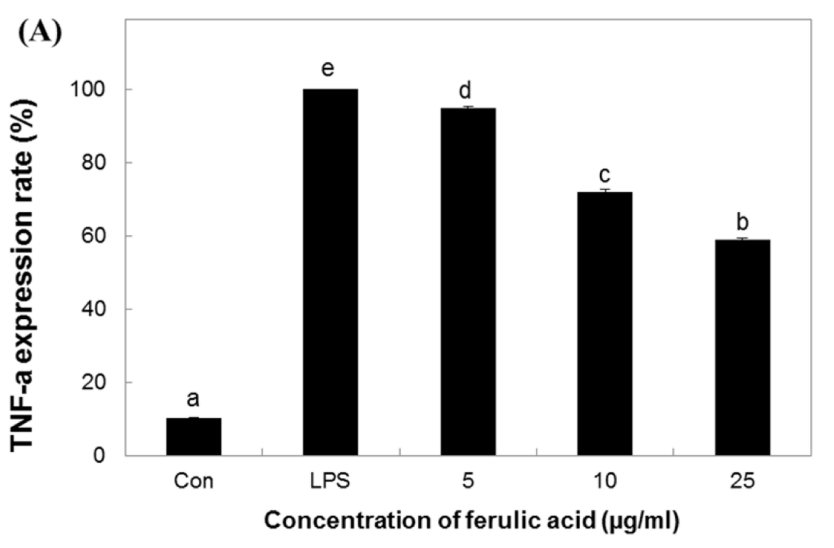

LPS $(1 \mu \mathrm{g} / \mathrm{mL})$

FA $(\mu \mathrm{g} / \mathrm{mL})$

$+$

$+$

$+$

Fig. 5 Production of pro-inflammatory cytokines in RAW 264.7 cells treated with different concentrations of ferulic acid. (A): TNF- $\alpha$, (B): IL-1 $\beta$. During a period of $24 \mathrm{~h}$ a treatment of cells was made with different concentrations of ferulic acid $(5,10$, and $25 \mu \mathrm{g} / \mathrm{mL})$ and LPS (1 $\mu \mathrm{g} / \mathrm{mL})$. The total of cytokines in the supernatant was evaluated by ELISA. The presented results are means \pm SD of three independent experiments. Means with different letters (a-e) above the bars for the same material are significantly different at the threshold of $5 \%$ of probability $(p<0.05)$ according to the test of multiple range of Duncan

NO production by suppressing iNOS protein expression. Similarly, COX-2 is expressed in a short period due to inflammatory stimulation and is known to be involved in the biosynthesis of prostaglandins (PGs), which are inflammatory and pain mediators $[26,27]$. To confirm the inhibitory effect of ferulic acid on the expression of COX-2, a treatment of LPS-stimulated RAW 264.7 cells was made with different concentrations of ferulic acid $(5,10$, and $25 \mu \mathrm{g} / \mathrm{mL}$ ) (Fig. 4B). The expression level of COX-2 in cells

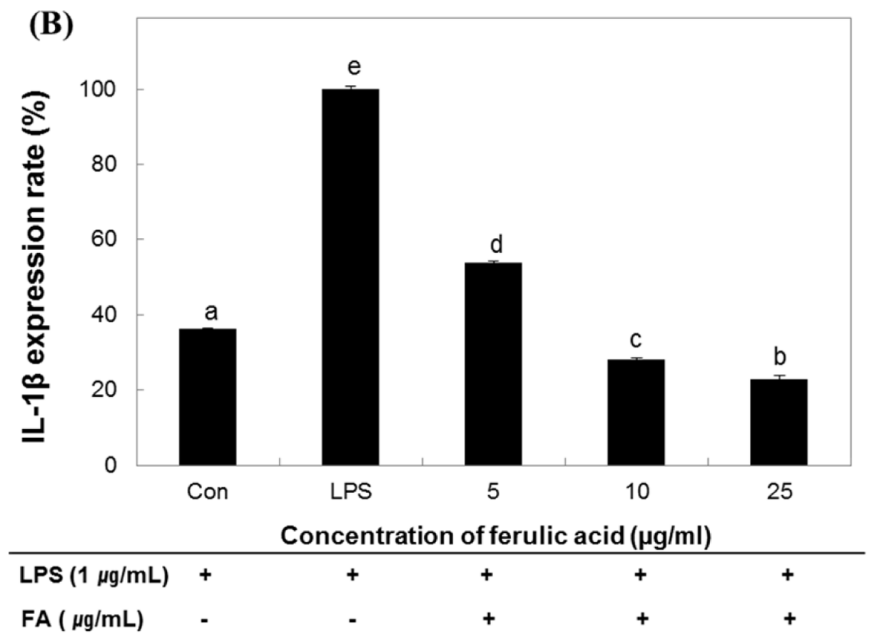




\section{Inhibitory effect of ferulic acid on the production of pro- inflammatory cytokines}

The effect of the ferulic acid on the inhibition of pro-inflammatory cytokines production by processing RAW 264.7 cell stimulated by LPS with the various concentrations of ferulic acid (5, 10 and 25 $\mu \mathrm{g} / \mathrm{mL}$ ) could be confirmed. TNF- $\alpha$ is a pro-inflammatory cytokine secreted by activated macrophages [28,29]. Our results confirmed that ferulic acid inhibits TNF- $\alpha$ production (Fig 5A). With $1 \mu \mathrm{g} /$ $\mathrm{mL}$ LPS, stimulated cells showed a TNF- $\alpha$ production nearly 10 times higher than that in un-stimulated cells. Nevertheless, it was suppressed in cells treated with ferulic acid in a concentrationproportional manner, as compared with the values in the LPSstimulated untreated cells.

Similarly, IL-1 $\beta$ is a pro-inflammatory cytokine secreted from activated macrophages, which is involved in immune reactions such as cell formation and apoptosis. As a pro-inflammatory cytokine, it is engaged in the formation of PGs and degrading enzymes such as collagenase. Thus, it is known to activate T-cells and B-cells and to induce inflammatory responses [30,31]. Our results confirmed that ferulic acid inhibits IL-1 $\beta$ production (Fig $5 B)$. IL- $1 \beta$ production in cells stimulated with $1 \mu \mathrm{g} / \mathrm{mL}$ LPS is nearly 3 times higher than that in the un-stimulated cells. However, it significantly decreased in cells treated with ferulic acid in a concentration-proportional manner, as compared with the values in the LPS-stimulated untreated cells.

Activated macrophages secrete IL-6, the third pro-inflammatory cytokine, which is associated with inflammatory reactions and tissue damage. It is also known to be secreted upon B-cell differentiation and T-cell proliferation [32,33]. It seems that ferulic acid suppresses the production of TNF- $\alpha$, IL- $1 \beta$ and then inhibits IL-6 secretion. In conclusion, our results demonstrated that ferulic acid suppresses the generation of TNF- $\alpha$ and IL- $1 \beta$, which are the initial pro-inflammatory factors, in a concentration-dependent manner. Therefore, ferulic acid could be used as a functional material for inhibiting inflammatory responses and promoting immunity.

\section{References}

1. Moncada S, Palmer RML, Higgs EA (1991) Nitric oxide: physiology, pathophysiology, and pharmacology. Pharm Rev 43: 109-142

2. Lee HJ, Sim BY, Bak JW, Kim DH (2014) Effect of Gami-sopungsan on inflammation and DNCB-induced dermatitis in NC/Nga in mice. Kor J Orient physiol pathol 28: 146-153

3. Noah TA, Zachary MW, Randy JN (2012) Inflammation: mechanisms, costs, and natural variation. Annual Review of Ecology, Evol Syst 43: 385-406

4. Christian RHR, Chris W (2002) Lipopolysaccharide endotoxins. Ann Rev Biochem 71: 635-700

5. O'Neill LAJ, Golenbock D, Bowie AG (2013) The history of toll-like receptors-redefining innate immunity. Nature Rev Immun 13: 453-460

6. Fitzgerald KA, Rowe DC, Barnes BJ, Caffrey DR, Visintin A, Latz E, Monks B, Pitha PM, Golenbock DT (2003) LPS-TLR4 signaling to IRF3/7 and NF-KB involves the toll adapters TRAM and TRIF. J Exp Med
198: 1043-1055

7. Singh NP, Schmidt RR (1989) Synthesis of a (4E, 8Z)-sphingadienine moiety containing cerebroside from Tetragonia tetragonoides with antiulcerogenic activity. J Carb Chem 8: 199-216

8. Hwang JR (2011) A study on bioactivities Tetragonia tetragonoides extracts as a cosmeceutical. Masters thesis. Seoul: Chung-Ang University

9. Aoki T, Takagi K, Hirata T, Suga T (1982) Two naturally occurring acyclic diterpene and norditerpene aldhydes from Tetragonia tetragonoides. Phytochem 21: 1361-1363

10. Okuyama E, Yamazaki M (1983) The principles of Tetragonia tetragonoides having an antiulcerogenic activity. I. Isolation and identification of sterylglucoside mixture (compound A). J Pharm Soc Japan 103: 43-48

11. Kato M, Takeda T, Ogihara Y, Shimizu M, Nomura T, Tomita T (1985) Studies on the structure of polysaccharide from Tetragonia tetragonoides. I. Chem Pharm Bull 33: 3675-3680

12. Mori K, Kinsho T (1988) Synthesis of sphingosine relatives, VII. Synthesis of anti-ulcerogenic cerebrosides isolated from Tetragonia tetragonoides. Euro J Org Chem 1988: 807-814

13. Lee KH (2008) Phytochemical constituents of Tetragonia tetragonoides and Paris verticillata. Doctoral thesis. Seoul: Sungkyunkwan University

14. Hwang SM (2009) Physiologically active compounds of Tetragonia tetragonoides. Masters thesis. Changwon: Changwon National University

15. Folin O, Denis W (1912) On phosphotungstic-phosphomolybdic compounds as color reagents. J Biol Chem 12: 239-243

16. Reissig JL, Storminger JL, Leloir LF (1955) A modified colorimetric method for the estimation of $N$-acetylamino sugars. J Biol Chem 217: 959-966

17. Carmichael J, DeGraff WG, Gazdar AF, Minna JD, Mitchell JB (1987) Evaluation of a tetrazolium-based semiautomated colorimetric assay: assessment of chemosensitivity testing. Can Res 47: 936-942

18. De la Mere PBD, Wilson MA, Rosser MJ (1973) The kinetics and mechanisms of additions to olefinic substances. Part XI. Stereochemistry of addition of chlorine acetate and of chlorine to some unsaturated compounds. J Chem Soc Perkin Trans 10: 1480-1490

19. Kim KS, Song JY, Lee IR (1999) Protective effects of the phenolic compounds from the leaves of Hedera rhombea on hepatic injury. Yakhak Hoeji 43: 516-525

20. Gentry EJ, Jampani HB, Keshavarz-Shokri A, Morton MD, Velde DV, Telikepalli H, Mitscher LA (1998) Antitubercular natural products: Berberine from the roots of commercial Hydrastis canadensis powder. Isolation of inactive 8-oxotetrahydrothalifendine, canadine, $\beta$-hydrastine, and two new quinic acid esters, hycandinic acid esters-1 and -2. J Natural Prod 61: 1187-1193

21. Meyer K (1947) The biological significance of hyaluronic acid and hyaluronidase. Physiol Rev 27: 335-359

22. Park TS (2008) A study of isolation of biological activities phenolic compounds from Rubus coreanus fruit and application for stability of cubosome on advanced dosage formulation. Doctoral thesis. Daegu: Daegu Haany University

23. Bredt DS, Snyder SH (1994) Nitric oxide: a pysiologic messenger molecule. Ann Rev Biochem 63: 175-195

24. Das P, De T, Chakraborti T (2014) Leishmania donovani secretory serine protease alters macrophage inflammatory response via COX-2 mediated PGE-2 production. Ind J Biochem Biophy 51: 542-551

25. Denlinger LC, Fisette PL, Garis KA, Kwon G, Vazquez-Torres A, Simon AD, Nguyen B, Proctor RA, Bertics PJ, Corbett JA (1996) Regulation of inducible nitric oxide synthase expression by macrophage purinoreceptors and calcium. J Biol Chem 271: 337-342

26. Merlie JP, Fagan D, Mudd J, Needleman P (1988) Isolation and characterization of the complementary DNA for sheep seminal vesicle prostaglandin endoperoxide synthase (cyclooxygenase). J Biol Chem 263: $3550-3553$

27. Kim JY, Jung KS, Jeong HG (2004) Suppressive effects of the kahweol and cafestol on cyclooxygenase-2 expression in macrophages. FEBS letters 569: 321-326 
28. Yoon WJ, Kim SS, Oh TH, Lee NH, Hyun CG (2009) Cryptomeria japonica essential oil inhibits the growth of drug-resistant skin pathogens and LPS-induced nitric oxide and pro-inflammatory cytokine production. Polish J Microb 58: 61-68

29. Tsai ML, Lin CC, Lin WC, Yang CH (2011) Antimicrobial, antioxidant, and anti-inflammatory activities of essential oils from five selected herbs. Biosci Biotech Biochem 75: 1977-1983

30. Kim HJ, Kim MS, Lee MW, Choi YW, Kim HH, Lee DI (2002) Effects of pectin-conjugated Ellagitannin on the IL-1 $\beta$, gene expression of macrophage. Yakhak Hoeji 46: 197-202

31. Sung HJ, Son SJ, Yang SJ, Rhee KJ, Kim YS (2012) Increased expression of interleukin- $1 \beta$ in triglyceride-induced macrophage cell death is mediated by p38 MAP kinase. BMB reports 45: 414-418

32. Kishimoto T (1989) The biology of interleukin-6. Blood 74: 1-10

33. Terry CF, Loukaci V, Green FR (2000) Cooperative influence of genetic polymorphisms on interleukin 6 transcriptional regulation. J Biol Chem 275: $18138-18144$ 